\title{
Recombinant Vaccinia-MUC1-B7 Vaccine
}

National Cancer Institute

\section{Source}

National Cancer Institute. Recombinant Vaccinia-MUC1-B7 Vaccine. NCI Thesaurus. Code C29409.

An admixture of recombinant vaccinia virus encoding MUC-1 and recombinant vaccinia virus encoding the murine T-cell co-stimulatory molecule B7.1. MUC-1 is a glycosylated mucin that is overexpressed in breast, lung, pancreatic, prostate, stomach, colon, and ovarian carcinomas. Vaccination with MUC-1 in combination with B7.1 may enhance the cytotoxic T cell (CTL) immune response to tumors expressing MUC-1, compared to vaccination with MUC-1 alone. ( $\mathrm{NCI04)}$ 